\title{
DISPERSED-REINFORCED DECORATIVE CONCRETE: INFLUENCE OF COMPOSITION FACTORS ON SHRINKAGE DEFORMATIONS
}

\author{
${ }^{1}$ Dovgan A.D., PhD, Associate Professor, \\ aleks.dovhan@gmail.com, ORCID: 0000-0002-6140-3159 \\ ${ }^{1}$ Vyrovoy V.M., D.Sc., Professor, \\ vyrovoy@ukr.net, ORCID: 0000-0001-8818-4112 \\ ${ }^{1}$ Odessa State Academy of Civil Engineering and Architecture \\ 4, Didrikhson str., Odessa, 65029, Ukraine \\ ${ }^{2}$ Dovgan P.M., \\ dovganpm@gmail.com, ORCID: 0000-0001-8204-1436 \\ ${ }^{2}$ Portal Ug, Odessa \\ 1, Parkova str., Odessa, 65031, Ukraine
}

\begin{abstract}
The results of the study of prescription factors influence on shrinkage deformations of multi-component material of architectural products are presented. Studies of the influence of composition factors on the value of composite samples shrinkage were carried out according to a symmetrical 5-factor design with 27 experiments. Depending on the nature of action on fine-grained concrete, variable raw materials are combined into two groups of factors - cement-sand system modifications, parameters of dispersion reinforcement. Based on the results of the conducted trials of the full-scale experiment, kinetic curves and correlation dependencies were built.

The results of researchers on introduction of active fine pozzolana instead of part of binder are confirmed - zeolite promotes growth of free shrinkage of concrete, especially during early hardening period up to 7 days with low level of its plasticization. At the same time the degree of carbonation of concrete compositions with a high dosage of pozzolana and superplasticizer is absent. The shrinkage measurement results show that hybrid fibers with high dispersion are stochastically distributed in the cement system, they form a three-dimensional framework, can affect the distribution of volumetric changes. As a result - it will allow to preserve decorative and operational characteristics of architectural products in time.

The amount of shrinkage deformations depends on the capillary pressure when the sample is dry, which is defined by the nature of porosity. In turn, the nature of porosity is responsible for the water absorption of the material. Therefore, in operation, optimization of decorative concrete compositions can be carried out for volume (or weight) water absorption and capillary water absorption. In order to estimate the durability of architectural elements, besides characteristics of strength and water absorption, it is necessary to take into account the carbonization stability of decorative concrete and the value of shrinkage deformations. It is planned, with the help of methods of computer materials science, to assess the influence of prescription factors on the dynamic elastic modulus of decorative concrete.
\end{abstract}

Keywords: decorative concrete, zeolite, superplasticizer, glass fiber, water absorption, porosity carbonation, strength, shrinkage deformations.

Introduction. Based on the research of the domestic and international scientific and professional community, high performance concrete is a composite material, which is characterized by high rates of maintainability, early and design strength, carbonization resistance, discoloration resistance, etc., including stable volume during the life cycle. In turn, such concretes are made on high-level cement (grades $500 \mathrm{i} 600$ ) with the use of organic-mineral modifiers and certain granulometry of fillers [1-4], require an increase in binder content and low water-cement ratio. The increased cement content, low $\mathrm{W} / \mathrm{C}$, presence of high-level fine-dispersed additives and type of fillers contribute to the growth of deformations of the composite shrinkage, which on its part lead to the emergence and development of technological cracks, as well as the cracks appearance depends on the services, elastic modulus, material volume and geometric shape of products [1-2, 5-10]. 
Therefore, ensuring the preservation of properties and decorative qualities of dispersed-reinforced decorative concretes is an urgent and pressing task.

Analysis of recent research and problem statement. Concrete shrinkage is one of the complex mechanisms of deformation in materials science, which fundamentally affects the long-term behavior of its micro- and macro-structures. Depending on deformation mechanisms, shrinkage is divided, in particular, into plastic, chemical (autogenic), while drying of solidified concrete and while carbonization [5, 11-12]. At the same time, all mechanisms of material shrinkage are associated with water movement. It is known, that only a small part of the mixing water (about 10-15\%) is hydrated and adsorbed on the surface of the solid phase, and the other part is free water, which fills pores and capillaries of the cement system. Cement system is characterized by large deformations of plastic shrinkage at micro-level, the least - at macro-level, because filler forms composite framework and perceives shrinkage. Also, the reason for the growth of shrinkage deformations, when concrete dries after 1st day of manufacture, - there are stresses in the material, caused by the action of capillary pressure in capillaries measuring $<1000 \AA$ [13], that, due to the limitation of volume compression of the solid skeleton, exceed the tensile strength of concrete, as a result, microcracks are formed [14] and, accordingly, embedded cracks develop in the cement system [9-10]. Shrinkage can also result in a peeling of the surface and deterioration of the decorative and operational characteristics of the material.

According to the data [15], it is not enough to use only the method of external humidity care during composites hardening, because «external» water penetrates through the concrete surface, which is characterized by early high strength, to a depth of a few millimeters. In general, the material shrinkage can not be eliminated, it is possible only to minimize its negative consequences. The introduction of chemical additives SRA (Shrinkage Reducing Admixture), specified in [7-8, 14, 16-17], makes it possible to reduce the cracking during shrinkage of high-quality concrete with decrease of surface tension of water, that is contained in capillary pores. However, it is worth using them with caution, because they delay hydration, wash out from the material under the influence of water with ease [14], reduce compressive strength [7, 16], frost resistance of the composite [17]. In order to reduce shrinkage deformations of cement composites, especially of high-performance low W/C concretes, scientists recommend to introduce fine-dispersed porous aggregates LWA (Light Weight Aggregate) $[11,15]$. These aggregates are able to provide the hardening composite with additional water on the inside, thereby creating continuity of hydration processes of clinker minerals and pozzolana, they reduce the possibility of self-drying of the material inner part and allow to achieve the breaking structure of pores in the structure of porous concrete space. However, most scientific studies indicate, that the uniform distribution of internal relative moisture throughout the entire volume of the cement system is the main parameter for achieving the above results on the influence of LWA. In turn, the efficiency of thin high-porous aggregates depends on the diameter of their pores, size of the particles, chemical composition, mineral characteristics and amount in the composite [11, 15, 18]. Also, as it is noted in [19], reduction of shrinkage can be only if the introduction of powdery fillers does not cause an increase in the mixture water requirement. In order to minimize cracking during shrinkage, it is proposed to introduce fibrous fillers [1], because dispersed reinforcement redistributes forces, which occur in concrete with early high strength, thereby blocking the development of cracks even in its plastic state phase [6].

In particular, the results of the research of many scientists on the influence of chemicalmineralogical composition of cement, its specific surface area, granulometry composition on the value of shrinkage are quite opposite on the conclusions. Thus, it is stipulated in [13], the greatest influence on the cement shrinkage is estimated by the content of $\mathrm{SO}_{3}$ and $\mathrm{C}_{3} \mathrm{~A}$, in $[1,19]-\mathrm{C}_{2} \mathrm{~S}$ and $\mathrm{C}_{3} \mathrm{~A}$. The fineness of cement grinding has little effect on concrete shrinkage, although the shrinkage of the solutions can grow with increasing the specific surface area of the binder. This is due to the fact, that fine-grained concrete with larger surface area has the highest degree of reactive sites for hydration reactions [20], especially with a content of particles, measuring less than 5 micrometres. [13]. As a result, the microstructure of the cement system is formed, characterized by large number of pores and small-diameter capillaries, where capillary pressure will be formed during concrete drying, that can lead to an increase in shrinkage deformations [11]. The results show in [21], that

Bulletin of Odessa State Academy of Civil Engineering and Architecture, 2020, no. 78, page 79-88 
thinner cement really leads to an increase in free shrinkage, but due to the early higher concrete strength, there is no tendency for rapid shrinkage cracking. According to A.A. Pashchenko et al., growth of cement dispersion increases shrinkage only in the initial period of hardening [19], and stabilizes - in the future. Also, the studies of O.Y. Berg et al., based on the assessment of the impact of the grade of concrete strength on the value of shrinkage deformations demonstrate, that the shrinkage value of high-strength concrete is not greater, than the conventional concrete shrinkage, made on the compositions with the same water consumption. Although, shrinkage deformations will grow with increased concrete strength and simultaneous increased kneading water of mixture [4]. It should be noted, no requirements to the values of shrinkage deformations of decorative concrete are foreseen on the basis of an analytical review of scientific and technical literature and normative documents (DSTU B A.1.1-59-95, DSTU B V.2.7-161:2008, DSTU B EN 13198:2016). Therefore, based on the above analysis, the minimum values of shrinkage deformations of the matrix material of architectural products can be obtained on compositions, which are characterized by low values of water saturation and carbonization of samples. Consequently, the objective of the research is to preserve the decorative and operational properties of architectural products in time by determining rational correlation of initial components, that minimize the deformation of composite shrinkage.

Materials and methods of research. In the development and investigation of the characteristics of fine-grained composite, according to a symmetrical 5-factor design with 27 experiments [22], two groups of factors of composition $X_{\mathrm{i}}$ varied in ranges $X_{\mathrm{i} 0} \pm \Delta X_{\mathrm{i}}$ [28], presented in the Table 1. Transition to dimensionless normalized variables $-1 \leq x_{\mathrm{i}} \leq+1$ is made according to

Table 1 - Variation of initial factors

\begin{tabular}{|c|c|c|c|c|}
\hline \multirow{2}{*}{$\mathrm{i}$} & \multirow{2}{*}{ Factors $X_{\mathrm{i}}$} & \multicolumn{3}{|c|}{ Levels } \\
\hline & & $x_{\mathrm{i}}=-1$ & $x_{\mathrm{i}}=0$ & $x_{\mathrm{i}}=+1$ \\
\hline \multicolumn{5}{|c|}{ I group - factors of the cement-sand system modification } \\
\hline 1 & $\begin{array}{l}\text { Fine-dispersed zeolite }(Z) \text {, introduced instead of a part of cement } \\
(\% \text { of binder mass) }\end{array}$ & 0 & 4 & 8 \\
\hline 2 & $\begin{array}{l}\text { Mass part of fine-grained sand }(G S) \text { in mixture with coarse-grained } \\
\text { sand (\% on } 100 \% \text { of sand mix mass) }\end{array}$ & 30 & 50 & 70 \\
\hline 3 & $\begin{array}{l}\text { Dosage of polycarboxylate based superplasticiser }(M F) \\
\text { (\% of binder mass) }\end{array}$ & 0.3 & 0.5 & 0.7 \\
\hline \multicolumn{5}{|c|}{ II group - parameters of disperse reinforcing } \\
\hline 4 & $\begin{array}{l}\text { Amount of alkali-resistant glass fiber }(F 6), 6 \mathrm{~mm} \text { long } \\
\text { (\% of concrete mix mass) }\end{array}$ & 0 & 0.015 & 0.03 \\
\hline 5 & $\begin{array}{l}\text { Quantity of alkali-resistant glass fiber }(F 12), 12 \mathrm{~mm} \text { long } \\
\text { (\% of concrete mix mass) }\end{array}$ & 0 & 0.015 & 0.03 \\
\hline
\end{tabular}

standard formulas [23]. The dosages of cement and sand with natural granulometry are fixed components of decorative concrete, with a ratio of 1:3.4 by weight of the mixture. The compositions of cement-sand compounds were manufactured with different water-cement ratio, where the requirements of equal mobility of concrete mixtures correspond to the grade $S 4$.

The shrinkage deformation was determined according to DSTU B V.2.7-239:2010 on prism specimens of square-section, measuring $40 \times 40 \times 160 \mathrm{~mm}$ on the methodology of DSTU B V.2.7216:2009. Measure the linear relative deformation of shrinkage $\left(\varepsilon_{\mathrm{cs}}, \mathrm{mm} / \mathrm{m}\right)$, caused by the cement hydration, decrease in the moisture of concrete samples and its carbonization, was being performed with the help of time indicators with graduation $0.01 \mathrm{~mm}$. In the first day after the manufacture of 
samples, autogenic shrinkage, due to chemical processes, was not covered by research. The initial reading of the longitudinal shrinkage deformation was started 24 hours after the dismantling of samples from the form, the value was taken after 3, 7, 14 days, and once every 2 weeks for 154 days with simultaneous control of mass loss of the sample thereafter.

Analysis of the results of the study. The kinetic curves were built according to the results of 27 tests of the natural experiment, reflecting dependence of shrinkage deformations $\left(\varepsilon_{\mathrm{cs}}\right.$ in $\left.\mathrm{mm} / \mathrm{m}\right)$ on the time measurement ( $\tau$, day). As a result of the combined effect of hydration of clinker minerals, pozzolana with Portland cement and gradual leveling of moisture samples with humidity of atmospheric air, it turned out, low plasticized composition of composite \#15 on coarse-grained sand with maximum level of hybrid reinforcement $(F 6=F 12=0.03 \%)$ without zeolite $(\# 15 \rightarrow$ $\varepsilon_{\mathrm{cs} . m i n}$, Fig. 1) is characterized by the minimum values of shrinkage deformations, on the entire length of study. Total shrinkage of concrete samples \#15 began to manifest only after 7 days of their

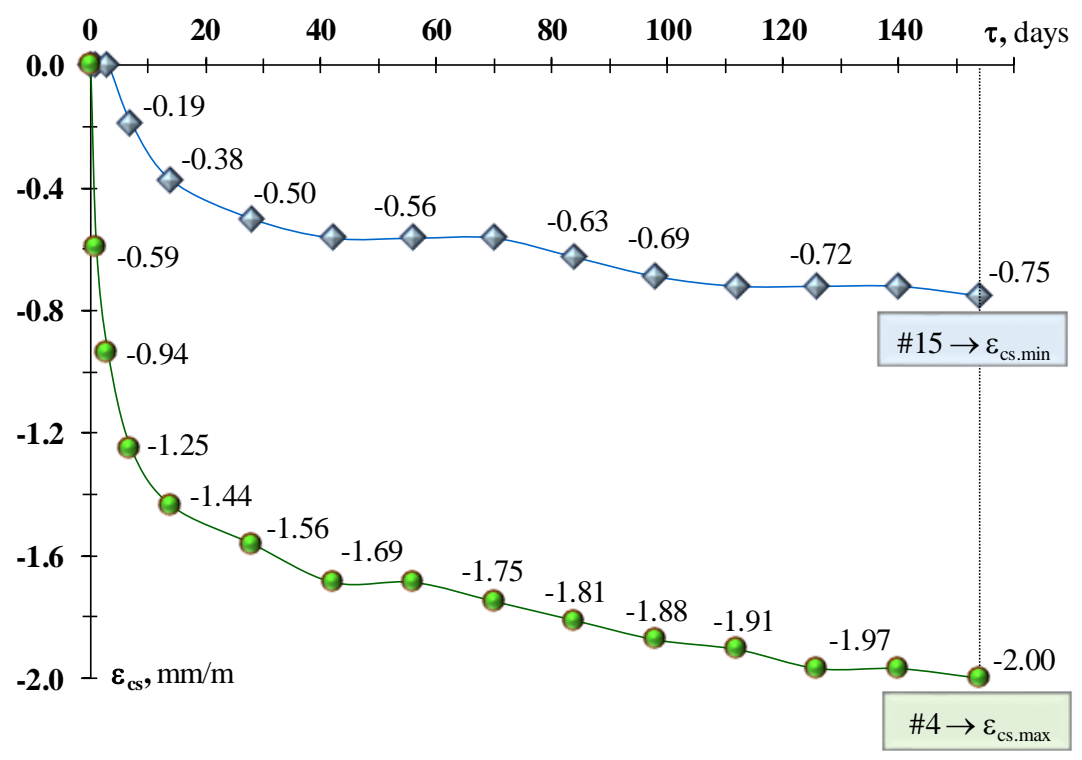

Fig. 1. Generalizing results of kinetics of linear relative shrinkage deformation $\left(\varepsilon_{\mathrm{cs}}, \mathrm{mm} / \mathrm{m}\right)$ of decorative composite

manufacture. In particular, numerical values $\varepsilon_{\mathrm{cs}}$ for the composition up to 98 days of the study inclusive were significantly lower (more than 1.5 times), than shrinkage of the control concrete composition \#16 ( $Z=F 6=F 12=0, G S=30, M F=0.3)$, which $\mathrm{W} / \mathrm{C}$ is $3.8 \%$ less. At the same time, the compression strength $f_{\mathrm{cm}}$ of samples composition \#15, both in equilibrium, dry as well as in watersaturated states of composite, is quite high (more than 20\%), than the control one \#16. In turn, a concrete with average dosages of modification factors of the cement matrix $\left(x_{1}=x_{2}=x_{3}=0\right)$ and parameters of dispersed reinforcement at the basic and high levels $\left(x_{4}=0, x_{5}=+1\right)$ is characterized by maximum shrinkage deformation with value of $-0.59 \mathrm{~mm} / \mathrm{m}$, in 48 hours after production of samples (composition \#25, W/C = 0.47). Further on all site of realization of criterion measurement $\varepsilon_{\mathrm{cs}}$, the low plasticized non-reinforced composition \#4 with high zeolite and grains of fine sand content $\left(\varepsilon_{\mathrm{cs.max}}\right.$, Fig. 1) differs in the maximum shrinkage values and respectively $\mathrm{W} / \mathrm{C}=0.53$. At the same time, it is worth noting - despite the fact, that the composition \#4 contains $8 \%$ of highporous pozzolana, removal of capillary moisture from samples (Fig. 2) is slower and shrinkage deformations are more intense. In general, concrete samples, with the content of zeolite $\mathrm{Z}$, lost no more in their mass, than samples without pozzolana (for example, compositions \#12 and \#15 with initial W/C 0.51 and 0.53 , respectively).

In the analysis of the dependence $\left\langle\varepsilon_{\mathrm{cs}}\right.$ of $\mathrm{m} »$ (Fig. 2) the structural porosity of composites should be taken into account. According to calculated micro porosity coefficient $K_{\mathrm{M}}$, macropores volume dependence $\left(\mathrm{V}_{\mathrm{m}}, \%\right)$ on $\mathrm{W} / \mathrm{C}$ [24] was established for all tested composites. In particular, for composition $\# 4 \mathrm{~V}_{\mathrm{m}}$ is equal to $60 \%$, and, accordingly, for others compositions: \#12 - 50\%, \#14

Bulletin of Odessa State Academy of Civil Engineering and Architecture, 2020, no. 78, page 79-88 


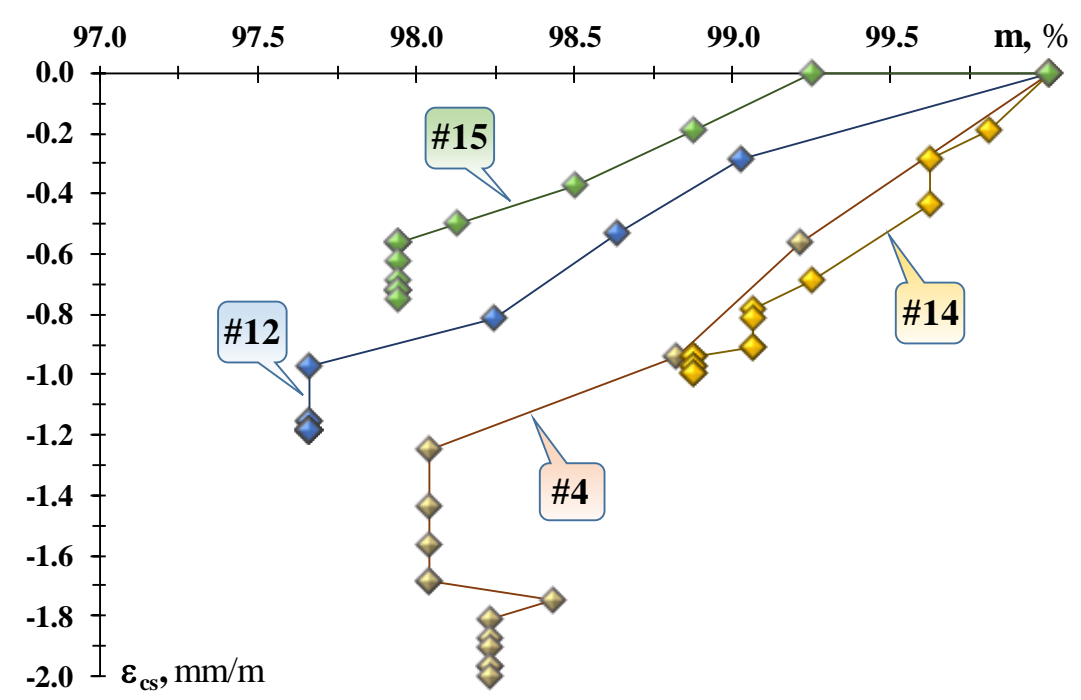

Fig. 2. Dependence of shrinkage on change of concrete samples humidity

- 48\%, \#15 - 58\%. Despite the fact, that the composition \#15 is characterized by an increased percentage of macropores and W/C, than the composition \#12, the composite loses less capillary moisture. This is probably due to the presence of hybrid zircon fibers ( $F 6$ and $F 12$ ) in the composition \#15, which can not only prevent formation of shrinkable cracks at early stages of solution hardening (www.owenscorning.com), but also lead to size reduction of large pores (Ramachandran V.S. et al.). Among the 27 composites, sample composition \#14 with W/C $=0.39$ has the least mass loss of $1.1 \%$ for 154 days, but at the same time, the longitudinal deformation of its shrinkage (in $-1 \mathrm{~mm} / \mathrm{m}$ ) is slightly higher than \#15 one. The low mass loss values for the sample \#14 can be explained by the microporous structure of the composite and breaking structure of the pores, because the density of the composition is high $\left(\rho_{\mathrm{c}}=2163 \mathrm{~kg} / \mathrm{m}^{3}\right)$, and the water absorption is minimal $\left(W_{\mathrm{M}}=2 \%\right.$ and $W_{\text {c.a }}=0.82 \mathrm{~kg} / \mathrm{m}^{2} \cdot \mathrm{h}^{0.5}$ after 28 days of saturation). As a result, concrete moisture evaporation is slowed down, the capillary pressure on the walls of pores can be reduced, and the decorative solution \#14 is characterized by greater mechanical strength in a water-saturated state (>20\%), as opposed to the decorative solution \#15.

In Fig. 3, for clarity, kinetic curves of growth rate of longitudinal shrinkage deformations are presented on the example of 6 different composites. The curves analysis shows, that developing compressive forces rapidly appear on the site of the study up to 42 days, and further, at the age of 98 days, the total shrinkage is stabilized. At the same time, the low-plasticized hybrid fiber-

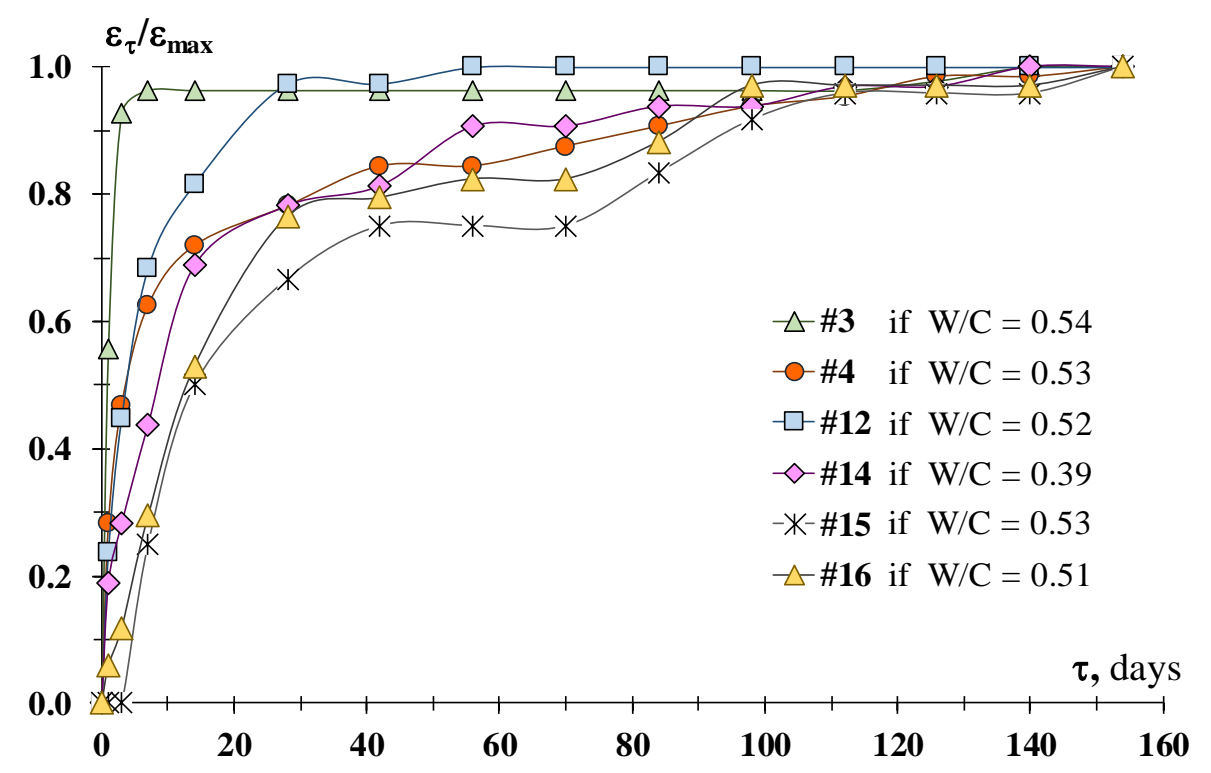

Fig. 3. Curves of growth rate $\varepsilon_{\mathrm{cs}}$ in time 
reinforced composition \#3 on fine-grained sand with a maximum level of modification of the zeolite additive $(Z=8 \%)$ is characterized by the highest growth rate $\varepsilon_{\mathrm{cs}}$. It should be noted, that the value of the criterion was $93 \%$ of its total value of $-0.84 \mathrm{~mm} / \mathrm{m}$ on 3rd day of measurement of shrinkage (or after 96 hours from the moment of dismounting of samples from moulds). The intensive development of shrinkage deformations is probably due to the high general activity of fine-dispersed particles of cement (CEM I 52.5 R) and pozzolana at early age of composite hardening \#3, that is respectively related to the greater need for water for hydration [24-25]. As shown in the work [26], the zeolite actually accelerates the process of initial structure formation of solutions more than $50 \%$. As a result, the composites are characterized by an increased content of cement stone neoplasms, and therefore, by high content of capillary-bound and adsorption-bound water [13], which will intensively evaporate during concrete hardening in natural conditions. Eventually, this leads to the development of enhanced astringent tensions in the capillaries of the binder system, and therefore - to the development of shrinkage deformations. Also, it should be noted, in the research of examples of composition \#3 on porosity and durability, it is found - the porous space of concrete consists of large and small macropores $\left(\approx 60 \%\right.$, as defined by $\left.K_{M}\right)$ with an intermittent structure [24], which is characterized by low indices of compressive strength. In turn, stochastically distributed glass fibers form a threedimensional framework in a cement-sand system, which can affect the distribution of volumetric changes. Since, the elastic modulus of fibers $\left(E_{\mathrm{f}}=72 \mathrm{GPa}\right)$ is much larger, than the elastic modulus of concrete $\left(E_{\mathrm{c} . \mathrm{d}}=29 \mathrm{GPa}\right.$ - for the control composition \#16 in a dry state), that means, fibers are able to perceive the bulk of tensions. The kinetic curve for composition \#15 experimentally demonstrates the statement in Fig. 3, when compared to the composition \#16.

In the opinion of many scientists $[5,11-13,19$, etc.], one of the main factors, affecting shrinkage during concrete drying, is an increase in the cement binder content and initial watercement ratio. The dependence of the influence of these factors on the value $\varepsilon_{\mathrm{cs}}$ on all site of its measurement was considered. It was found, the closest correlation connection occurs on 98 day, when shrinkage deformations stabilize in the composites. The analysis of the diagram in Fig. 4 shows - the general concretes shrinkage, with equal requirements for mixtures placeability, is higher, the greater W/C is, and with a slightly higher content of calcium hydrosilicates in the cement system, but at the same time, such communication is insignificant.

The value of shrinkage deformations is affected by porosity (defined through water absorption $W$ ) and dynamic elastic modulus $E_{\mathrm{c}}$ of decorative concretes. The meaning of these properties, obtained for 27 composites, can be seen in the scatter diagrams. As indicated in Fig. 5, deformations develop more intensively in concrete with big water absorption, and respectively, develop less intensively in concrete with high spring properties, hence the interdependence of characteristics $W$ and $E_{\mathrm{c}}$ is observed with a value $\varepsilon_{\mathrm{cs}}$. It is worth noting, the most significant correlation is between the compression strength $f_{\mathrm{cm}}$ and $E_{\mathrm{c}}$ of composites of dry «d» and equilibrium «n» state, because their correlation coefficients $(r)$ correspond to the values of $r\left\{f_{\mathrm{cm} . \mathrm{d}}, E_{\mathrm{c.d}}\right\}=0.73$ and $r\left\{f_{\mathrm{cm} . n}, E_{\mathrm{c} . \mathrm{n}}\right\}=0.76$. At the same time, ratios of $f_{\mathrm{cm}}$ and $\varepsilon_{\mathrm{cs}}$ are less significant $r\left\{f_{\mathrm{cm} . \mathrm{d}}, \varepsilon_{\mathrm{cs}}\right\}=-0.32$ and $r\left\{f_{\mathrm{cm} . \mathrm{n}}, \varepsilon_{\mathrm{cs}}\right\}=-0.26$.

Taking into account the own results of the research [27] of carbonization stability of decorative concrete, it is worth noting, the carbonization value of compositions depends on the degree of hydration of clinker minerals of cement, content of binder and pozzolana. Furthermore, the initial W/C impacts on the criterion by changing the porosity and volume of the through pores. In particular, it was also discovered, that compositions of composites with maximum levels of superplasticizer and zeolite are characterized by high carbonization resistance and lower values of shrinkage deformations, because their water absorption by volume and capillary water absorption are small, respectively, $W_{\mathrm{v}}<4.5 \%$ and $W_{\text {c.a }}<1.1 \mathrm{~kg} / \mathrm{m}^{2} \cdot \mathrm{h}^{0.5}$ after 28 days of saturation.

Conclusions. The decorative and operational properties of architectural products in time depend on rational ratios of initial components. The researchers results on introduction of active high-dispersed pozzolana instead of part of binder are confirmed - zeolite contributes to the growth of free shrinkage of concrete, especially in early period of hardening up to 7 days, with a low level of its plasticization. At the same time, there is no degree of carbonization of concrete compositions with high dosages of pozzolana and superplasticizer. Shrinkage measurements show, that stochastically distributed hybrid

Bulletin of Odessa State Academy of Civil Engineering and Architecture, 2020, no. 78, page 79-88 


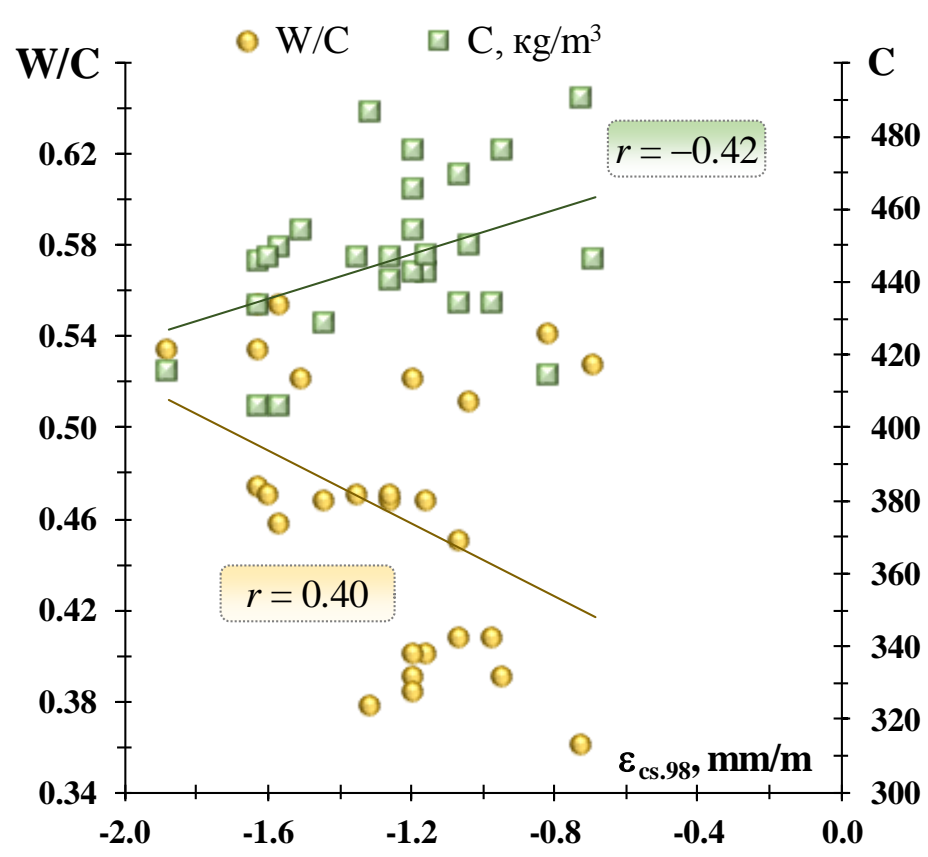

Fig. 4. The influence of the binder expenditure and water-cement ratio

on the linear relative shrinkage deformation of 27 compositions of decorative concrete

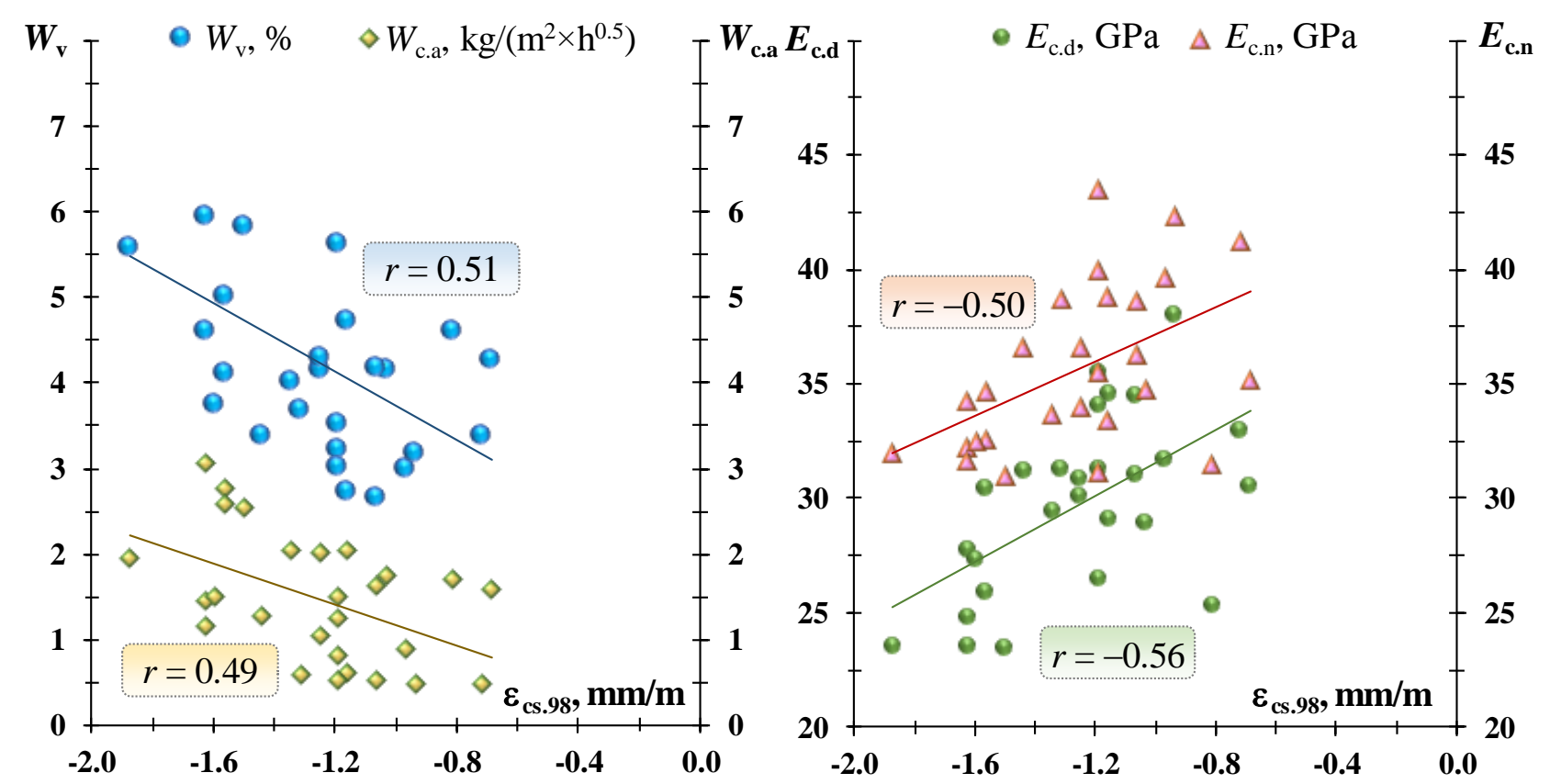

Fig. 5. Ratio of characteristics of decorative composites to shrinkage deformation

high-dispersed fibers in the cement system, forming a three-dimensional framework, can affect the distribution of volumetric changes. The amount of shrinkage deformations depends on the capillary pressure while drying out the sample, which is determined by the nature of the porosity. The nature of the porosity is, in turn, responsible for the water absorption of the material. Therefore, in the work, optimization of decorative concrete compositions will be carried out by water absorption, since the characteristic for the material is normative. It is planned to assess the influence of prescription factors on the dynamic elastic modulus of decorative concrete, using the computer methods in materials science.

\section{References}

[1] Y.M. Bazhenov, V.S. Demyanov, V.I. Kalashnikov, The modified hidh-quality concrete. Moscow, 2006. 
[2] Steven H. Kosmatka, et al., Design and Control of Concrete Mixtures. Portland Cement Association. 14th ed. 2002.

[3] L.J. Dvorkin, E.M. Babich, High-strength quick-hardening concrete and fiber-reinforced concretes: monograph. Rivne, 2017.

[4] O.YA. Berg, E.N. Shcherbakov, G.N. Pisanko, Vysokoprochnyj beton. M.: Izd-vo literatury po stroitel'stvu, 1971.

[5] Yuaj Yuan', Van Lin, Tyan' Pe, Vysokokachestvennyj cementnyj beton s uluchshennymi svojstvami. Moskva: Izd-vo ASV. 2014.

[6] Ola Adel Qasim, "Experimental investigation on autogenous shrinkage of high and ultrahigh strength concrete", IOP Conf. Series: Materials Science and Engineering, vol, 454, no. 1 2018. Available: https://iopscience.iop.org/article/10.1088/1757899X/454/1/012067/pdf

[7] Behzad Hatami, Amir Mohammad Ramezanianpour and Amir Saedi Daryan, "Investigation on the Effect of Shrinkage Reducing Admixtures on Shrinkage and Durability of High Performance Concrete", Journal of Testing and Evaluation, vol. 46, no. 1, pp. 144-150, 2018.

[8] K. Loboda, S. Lakhtaryna, "Effect of Admixtures on the Restrained Shrinkage of Highb Quality Concrete", Donbas National Academy of Civil Engineering and Architecture, vol. 3 (119), pp. 104-108, 2016.

[9] V.N. Vyrovoy, V.S. Dorofeev, V.G. Suhanov, Compositional building materials and structures. Structure, self-organization, properties: monograph. Odessa, 2010.

[10] A.D. Dovgan, V.M. Vyrovoy, P.M. Dovgan, "Crack resistance of decorative composites", IOP Conf. Series: Materials Science and Engineering, vol. 708, 2019. Available: https://iopscience.iop.org/article/10.1088/1757-899X/708/1/012084/pdf

[11] Peter Taylor, Xuhao Wang, Concrete Pavement Mixture Design and Analysis (MDA): Factors Influencing Drying Shrinkage. National Concrete Pavement Technology Center, 2014.

[12] Z.N. Cilosani, Usadka i polzuchest' betona. Tbilisi: «Mecniereba», 1979.

[13] A. Sheikin, Yu. Chekhovsky, M. Brusser, The structure and properties of cement concrete. M.: Stroyizdat, 1979.

[14] M. Alexa, B. Kucharczyková, D. Kocáb, P. Daněk, "Experimental determination of the influence of additives on shrinkage in self-compacting concrete", IOP Conf. Series: Materials Science and Engineering, vol. 549, 2019. Available: https://iopscience.iop.org/article/10.1088/1757-899X/549/1/012009/pdf.

[15] Dale P. Bentz, W. Jason Weiss, Internal Curing: A 2010 State-of-the Art Review. National Institute of Standards and Technology, 2011.

[16] Heinere Howard Ah-Sha, David H Sanders, M. Saiid Saiidi, Early Age Shrinkage and Cracking of Nevada Concrete Bridge Decks. Nevada Department of Transportation, 2001.

[17] M. Peterson, High-performance and self-compacting concrete in house building. Field tests and theoretical studies of possibilities and difficulties, Division of Building Materials, LTH, Lund University, 2008.

[18] Memduh Nas, Şirin Kurbetci, "Mechanical, durability and microstructure properties of concrete containing natural zeolite", Computers and Concrete, vol. 22, no. 5, 2018. https://www.researchgate.net/publication/299418865.

[19] A.A. Pashchenko et al., Teoriya cementa. K.: Budivelnyk, 1991.

[20] A. Sharma, T. Sirotiak, X. Wang et al., Portland Limestone Cement for Reduced Shrinkage and Enhanced Durability of Concrete. Magazine of Concrete Research, 2019.

[21] Swapnil Deshpande, David Darwin, JoAnn Browning, "Evaluating free shrinkage of concrete for control of cracking in bridge decks", Structural Engineering and Engineering Materials SM Report, no. 89, 2007.

[22] T.V. Lyashenko, A.D. Dovgan, P.M. Dovgan, "Decorative concrete with hybrid glass fibre: design and first results of the experiment", Bulletin of Odessa State Academy of Civil Engineering and Architecture, vol. 70, pp. 99-105, 2018. 
[23] V.A. Voznesensky, T.V. Lyashenko, B.L. Ogarkov, Numerical methods of solving building technological problems with computer. Kiev: Vischa Shkola, 1989.

[24] A.D. Dovgan, V.M. Vyrovoy, P.M. Dovgan, "Water absorption as a function of decorative concrete warehouses", Collection of scientific works "Resource and economic materials, structures, buildings and constructions», 2020. Accepted by the editorial board for printing.

[25] N.M. Zaichenko, High-strength fine-grined concrete with a complex modified microstructure: monograph. Donbas National Academy of Civil Engineering and Architecture, 2009.

[26] A.D. Dovgan, P.M. Dovgan, T.V. Lyashenko, "The influence of zeolite and glass fibers on the kinetics of the cement compositions structure formation", National university of water and environmental engineering Messenger, vol. (82), pp. 273-287, 2018.

[27] A.D. Dovgan, V.M. Vyrovoy, P.M. Dovgan, N.V. Hlitsov, "Carbonization stability of decorative concrete", Modelling and Optimization of Building Composites. Odessa, 2019, pp. 45-50.

[28] T.V. Lyashenko, V.A. Voznesensky, Composition-Process Fields Methodology in Computational Building Materials Science. Astroprint, Odessa 2017, pp 168.

\title{
ДИСПЕРСНО-АРМОВАНИЙ ДЕКОРАТИВНИЙ БЕТОН: ВПЛИВ ФАКТОРІВ СКЛАДУ НА ДЕФОРМАЦІЇ УСАДКИ
}

\author{
${ }^{1}$ Довгань О.Д., к.т.н., доцент, \\ aleks.dovhan@gmail.com, ORCID: 0000-0002-6140-3159 \\ ${ }^{1}$ Вировой В.М., д.т.н., професор, \\ vyrovoy@ukr.net, ORCID: 0000-0001-8818-4112 \\ ${ }^{1}$ Одеська державна академія будівництва та архітектури \\ вул. Дідріхсона, 4, м. Одеса, 65029, Україна \\ 2 Довгань П.М., \\ dovganpm@gmail.com, ORCID: 0000-0001-8204-1436 \\ ${ }^{2}$ ПП «Портал Юг» \\ вул. Паркова, 1, м. Одеса, 65031, Україна
}

\begin{abstract}
Анотація. Представлені результати дослідження впливу рецептурних факторів на деформації усадки багатокомпонентного матеріалу архітектурних виробів. Дослідження впливу факторів складу на величину усадки зразків композиту проводилося по симетричному 5факторному плану з 27-ми числом дослідів. В залежності від характеру дії на дрібнозернистий бетон варійовані сировинні матеріали об'єднані в дві групи факторів - модифікації цементнопіщаної системи, параметри дисперсного армування. За отриманими результатами проведених дослідів натурного експерименту будувалися кінетичні криві та кореляційні залежності.

Підтверджено результати дослідників щодо введення активного тонкодисперсного пуцолану замість частини в'яжучого - цеоліт сприяє зростанню вільної усадки бетону, особливо в ранній період твердіння до 7 діб з низьким рівнем його пластифікації. При цьому карбонізація складів бетону з високим дозуванням пуцолану і суперпластифікатора відсутня. Результати вимірювання усадки показують, що стохастично розподілені гібридні високодисперсні волокна в цементній системі, утворюючи тривимірний каркас, можуть впливати на розподіл об'ємних змін. В результаті - це дозволить зберегти декоративноексплуатаційні характеристики архітектурних виробів в часі.

Величина деформацій усадки залежить від капілярного тиску при висиханні зразка, який визначається характером пористості. Характер пористості, в свою чергу, є відповідальним за водопоглинання матеріалу. Тому в роботі оптимізація складів декоративного бетону буде проводитися по водопоглинанню, оскільки характеристика для матеріалу є нормативною.

Для оцінки довговічності архітектурних елементів, окрім характеристик міцності і водопоглинання варто брати до уваги карбонізаційну стійкість декоративного бетону i величину деформацій усадки. Планується, за допомогою методів комп'ютерного
\end{abstract}


матеріалознавства, оцінити вплив рецептурних факторів на динамічний модуль пружності декоративного бетону.

Ключові слова: декоративний бетон, цеоліт, суперпластифікатор, скляна фібра, водопоглинання, карбонізаційна стійкість, міцність, деформації усадки.

\title{
ДИСПЕРСНО-АРМИРОВАННЫЙ ДЕКОРАТИВНЫЙ БЕТОН: ВЛИЯНИЕ ФАКТОРОВ СОСТАВА НА ДЕФОРМАЦИИ УСАДКИ
}

\author{
${ }^{1}$ Довгань А.Д., к.Т.н., доцент, \\ aleks.dovhan@gmail.com, ORCID: 0000-0002-6140-3159 \\ ${ }^{1}$ Выровой В.Н., д.Т.Н., профессор, \\ vyrovoy@ukr.net, ORCID: 0000-0001-8818-4112 \\ ${ }^{1}$ Одесская государственная академия строительства и архитектуры \\ ${ }^{2}$ Довгань П.М., \\ dovganpm@gmail.com, ORCID: 0000-0001-8204-1436 \\ ${ }^{2}$ ПП «Портал Юг» \\ ул. Парковая, 1, г. Одесса, 65031, Украина
}

\begin{abstract}
Аннотация. Представлены результаты исследования влияния рецептурных факторов на деформации усадки многокомпонентного материала архитектурных изделий. Исследования влияния факторов состава на величину усадки образцов композита проводилось по симметричному 5 факторному плану с 27 -ми числом опытов. В зависимости от характера действия на мелкозернистый бетон варьируемые сырьевые материалы объединены в две группы факторов - модификации цементно-песчаной системы, параметры дисперсного армирования. По полученным результатам проведенных опытов натурного эксперимента строились кинетические кривые и корреляционные зависимости.
\end{abstract}

Подтверждены результаты исследователей относительно введения активного тонкодисперсного пуццолана взамен части вяжущего - цеолит способствует росту свободной усадки бетона, особенно в ранний период твердения до 7 суток с низким уровнем его пластификации. При этом карбонизация составов бетона с высокой дозировкой пуццолана и суперпластификатора отсутствует. Результаты измерения усадки показывают, что стохастично распределенные гибридные высокодисперсные волокна в цементной системе, образуя трехмерный каркас, могут влиять на распределение объемных изменений. В результате - это позволит сохранить декоративно-эксплуатационные характеристики архитектурных изделий во времени.

Величина деформаций усадки зависит от капиллярного давления при высыхании образца, которое определяется характером пористости. В свою очередь характер пористости является ответственным за водопоглощение материала. Поэтому в работе оптимизация составов декоративного бетона может проводиться по водопоглощению по объему (или массе) и капиллярному водопоглощению, поскольку характеристика для материала является нормативной.

Для оценки долговечности архитектурных элементов, кроме характеристик прочности и водопоглощения стоит принимать во внимание карбонизационную устойчивость декоративного бетона и величину деформаций усадки. Планируется, с помощью методов компьютерного материаловедения, оценить влияние рецептурных факторов на динамичный модуль упругости декоративного бетона.

Ключевые слова: декоративный бетон, цеолит, суперпластификатор, стеклянная фибра, водопоглощение, карбонизационная стойкость, прочность, деформации усадки.

Стаття надійшла до редакції 29.12.2019 